\title{
Nekton use of regularly-flooded saltmarsh cordgrass habitat in North Carolina, USA
}

\author{
William F. Hettler, Jr \\ National Marine Fisheries Service, NOAA, Southeast Fisheries Center, Beaufort Laboratory, Beaufort, North Carolina 28516 , \\ USA
}

\begin{abstract}
Species composition, numbers and biomass of the nekton community on a regularlyflooded Spartina marsh near Beaufort, North Carolina, USA, was estimated for 1 yr using modified $10 \mathrm{~m}$ block nets. Thirty-five fish species dominated by mummichog Fundulus heteroclitus, spot Leiostomus xanthurus and pinfish Lagodon rhomboides were captured from the marsh surface. Numbers were greatest in April (1300 per $10 \mathrm{~m}$ of marsh edge); biomass was greatest in September ( $900 \mathrm{~g} \mathrm{per} 10 \mathrm{~m}$ ). Stream Order 1 (rivulet) marsh was occupied by fewer species, but contained greater numbers and biomass than Stream Order 3 (channel) marsh
\end{abstract}

\section{INTRODUCTION}

The role of saltmarsh as habitat for estuarine nekton is receiving increased attention in response to wetland loss associated with coastal development (e.g. Weinstein 1979, Bozeman \& Dean 1980, Gilmore et al. 1982, Boesch \& Turner 1984, Rogers et al. 1984, Rozas \& Hackney 1984, Lipcius \& Subrahmanyam 1986). In the last decade emergent vegetation structure has been recognized to be of direct use to juvenile and small adult fishes (Kneib \& Stiven 1978). Previously, its main importance was seen as a source of carbon, detritus, and in the secondary production of invertebrate prey that could be transported into adjacent tidal creeks and bays.

Sampling in intertidal vegetation for fish or crustaceans is difficult, but efforts to study this habitat have shown that the marsh surface is used by nekton (Talbot \& Able 1984, McIvor \& Odum 1986, Rozas \& Odum 1987). Use of tidally inundated saltmarsh cordgrass Spartina alterniflora by the entire nekton community throughout the year has not been reported, although studies have been conducted in this habitat type, e.g. Kneib (1986) on mummnichog Fundulus heteroclitus and Zimmerman \& Minello (1984) on shrimp Penaeus spp. and other nekton including fishes. With ca 650000 ha of salt marsh in US Atlantic coast estuaries from Florida to North Carolina, this habitat may exceed the area of other important estuarine nursery habitats such as tidal creeks and submerged aquatic vegetation
(SAV) (however, estimates of these areas are not available for comparison). An estimate of the species composition, numbers and biomass of species using salt marsh habitat would be useful for habitat management and would enhance our understanding of the life history of estuarine species. In this study, I sampled a saltmarsh for 1 yr to measure fish and macrocrustacean abundance, and to compare the nekton of 2 marsh microhabitats.

\section{STUDY AREA AND METHODS}

Collections were made from May 1986 to April 1987 in the lower Newport River estuary, N. Carolina, USA, in a 150 ha regularly-flooded, polyhaline marsh located $3 \mathrm{~km}$ from the Atlantic Ocean and $1 \mathrm{~km}$ north of Pivers Island $\left(34^{\circ} 43^{\prime} \mathrm{N}, 76^{\circ} 40^{\prime} \mathrm{W}\right)$ (Fig. 1). Spartina alterniflora is the primary intertidal vegetation. The marsh is surrounded on 3 sides by channels with varying water depths from 3 to $10 \mathrm{~m}$ and on the fourth side by a causeway.

Two habitat types within a $250 \mathrm{~m}$ radius were sampled: channel-edge marsh and rivulet-edge marsh. This provided a $2 \times 2 \times 2$ design: 2 habitat types, 2 locations for each habitat type, and a pair of plots at each location. Channel marsh sites bordered a third order tidal creek (Odum 1984). Water in front of this habitat never drained more than 1 to $2 \mathrm{~m}$ away from the vegetation at low tides. Rivulet marshes were at the 


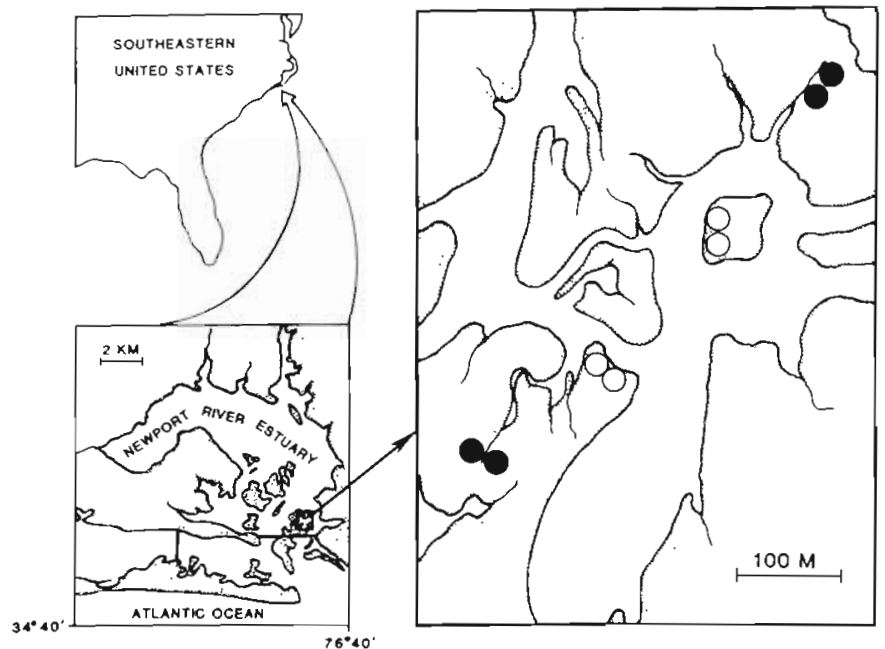

Fig. 1. Study area near Beaufort, North Carolina, USA. (0) Channel marsh sites; $(\bullet)$ rivulet marsh sites

upper end of first order streams. Rivulets adjacent to these marshes were usually completely drained at low tide leaving only residual pools.

Each plot was evaluated for stem density, stem height, sediment size and marsh surface slope. Stem densities of Spartina were estimated by counting the number of stems in $0.25 \mathrm{~m}$ square quadrats at 0,5 and $10 \mathrm{~m}$ into the marsh. Sediment was also collected at these points in each quadrat, dried at $65^{\circ} \mathrm{C}$ and analyzed for organic content and percent silt-clay. Pulverized and weighed subsamples were placed in a muffle furnace at $500^{\circ} \mathrm{C}$ for $24 \mathrm{~h}$ and the weight of

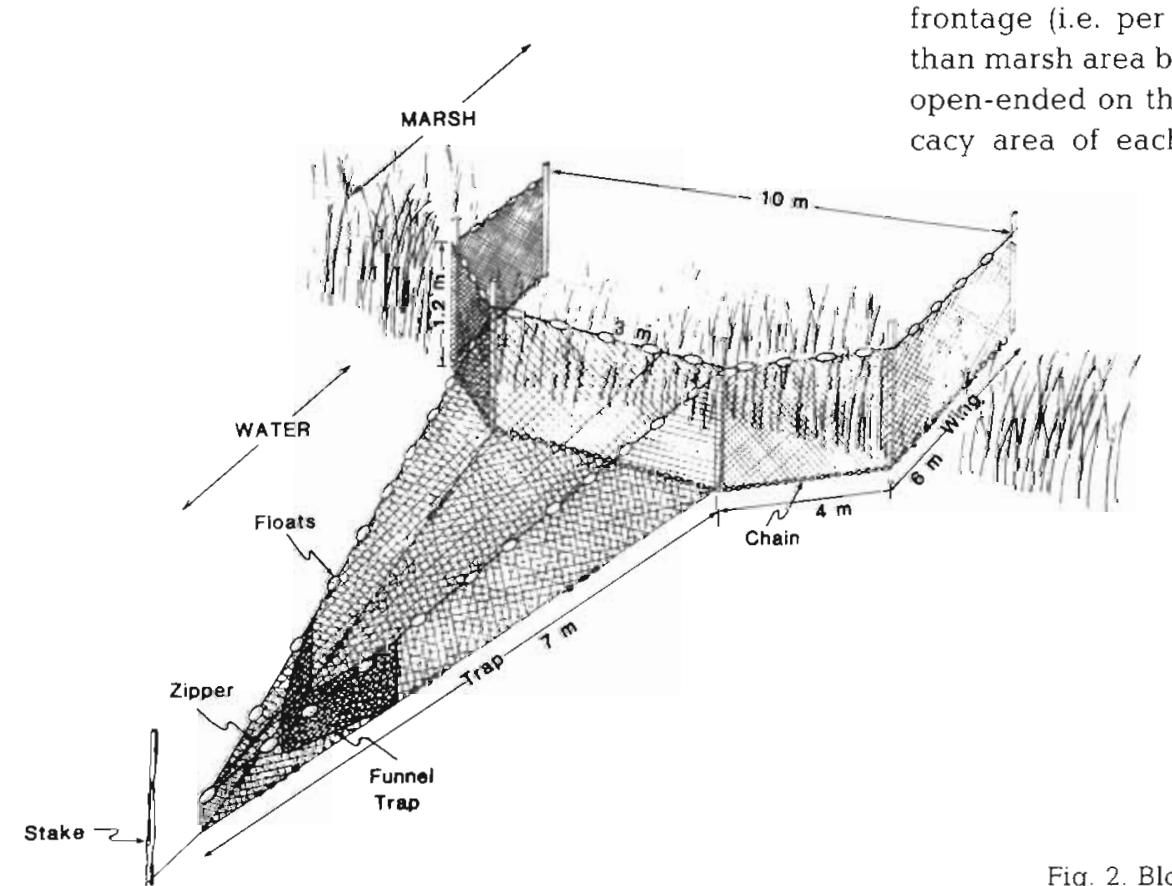

Fig. 2. Block net design and dimensions organic content was assumed equal to the weight loss. The remaining sediment was weighed, wetted using sodium hexametaphosphate solution, and wet seived. Material retained on $4.00 \mathrm{~mm}$ (shell) and $0.063 \mathrm{~mm}$ (sand) sieves was redried, and the difference between the initial total dry weight and the sum of these 2 size fractions was measured as the silt-clay content (modified from American Society for Testing and Materials 1963). Average slope was measured over the first $10 \mathrm{~m}$ of marsh. On sampling days at each plot, water temperature, salinity and water depth were measured at high slack tide.

Fish and crustaceans were sampled with modified $10 \mathrm{~m}$ block nets set at high slack tide (Fig. 2). Each plot was sampled monthly during daylight, at new moon spring tides, as the tide fell. Two paired plots were sampled simultaneously per day, a total of 4 sampling days each month. Permanent stakes were set into the marsh to which the wings and the trap of each block net ( $2 \times 3 \mathrm{~mm}$ tarred nylon) were attached on the day of sampling. The wings extended $6 \mathrm{~m}$ into the marsh to prevent fish and crustaceans from entering the trap if they moved along the marsh edge. The trap was enclosed on all 4 sides by nylon mesh. A mesh funnel in the tail bag was installed to reduce escape. Before setting the trap at high tide, the area between the trap stakes and the marsh was swept with a net to exclude fish not actually in the vegetation. Nekton was removed from the trap after all water had drained from the marsh surface, usually 4 to $5 \mathrm{~h}$ after high tide. The catch was iced immediately. In the laboratory chilled specimens were identified, counted and weighed.

Biomass and numbers are reported in terms of marsh frontage (i.e. per $10 \mathrm{~m}$, the width of the trap) rather than marsh area behind the nets because the nets were open-ended on the upland side, because the trap efficacy area of each plot was different, and because I 
could not determine the distance captured nekton penetrated into the marsh before capture. Distribution of nekton on the marsh surface may have been skewed towards the marsh edge, thereby increasing calculated nekton densities on channel plots with smaller areas relative to rivulet plots with larger areas. To estimate catch per $\mathrm{m}^{2}$, the area from which nekton could be collected was considered to include one-half the distance of the flooded surface to the next adjacent drainage rivulet or channel multiplied by $10 \mathrm{~m}$

\section{RESULTS}

\section{Habitat description and comparison}

Water temperatures, salinities and water depth above mean low water at high tide were the same on any given day at all habitats because of the close proximity of stations. Daily hydrographic variations due to wind-driven tidal effects were averaged for each month (Fig. 3). Salinities were usually above $32 \mathrm{ppt}$, but dropped below 30 ppt during mid-winter and again during late summer because of increased rainfall. Predictable equinoxial spring tides occurred in March and September. The highest tides occurred in October to December because strong northerly winds increased water levels above predicted tides.

Average organic content (chamnel $=8.8 \% \pm 2.0 \mathrm{SD}$, rivulet $=6.1 \% \pm 1.8 \mathrm{SD}, n=2$ ) and silt-clay content (channel $=57.6 \% \pm 12.7 \mathrm{SD}$, rivulet $=54.9 \% \pm 20.4$ $\mathrm{SD}, n=2$ ) of sediments were not significantly different (ANOVA, $p<0.05$ ) between the 2 habitats.

Stem densities of Spartina averaged $890 \pm 112 \mathrm{SD}$ stems per $\mathrm{m}^{2}$ in channel habitat and $516 \pm 210 \mathrm{SD}$ stems per $\mathrm{m}^{2}$ in rivulet habitat. Stem heights at all plots were about 80 to $100 \mathrm{~cm}$ near the water/grass edge and 60 to $80 \mathrm{~cm} 10 \mathrm{~m}$ into the marsh.

The area of trap efficacy averaged $176 \mathrm{~m}^{2} \pm 23.7 \mathrm{SD}$ in the 4 channel plots and $295 \mathrm{~m}^{2} \pm 46.5 \mathrm{SD}$ in the 4 rivulet plots. The average slope of the intertidal area in channel marsh was twice the slope of the rivulet marsh (5 vs $2 \mathrm{~cm}$ $\mathrm{m}^{-1}$ ). Most of the vertical change in the channel plots was due to a steep bank at the vegetation line, whereas the slope of the rivulet plots was uniform and gradual. At high tide, seawater flooded $15.4 \mathrm{~m}$ into the marsh at the station with the steepest slope and to a distance of $33.0 \mathrm{~m}$ at the station with the shallowest slope.

\section{Fishes}

Twenty families and 35 species of fish were collected from the marsh surface (Table 1). Eight species were residents, 26 were estuarine-dependent transients and
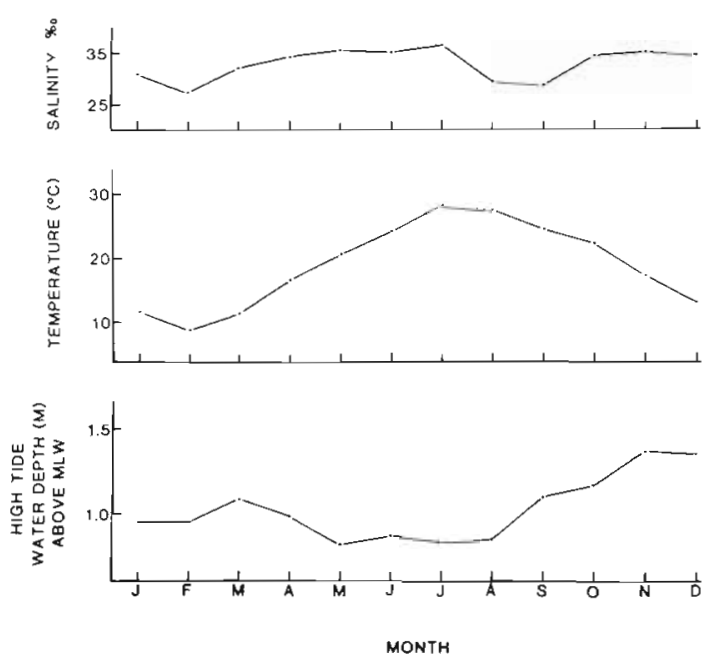

Fig. 3. Average high tide salinities, temperatures and high tide water heights above mean low water by month

5 were marine visitors. Because residents complete their life cycle in the estuary, both juveniles and adults were captured. Only juveniles (with a few exceptions) of transients and marine visitors were caught. Ten species accounted for $88 \%$ of the biomass and $92 \%$ of the numbers (Table 1). Mummichog Fundulus heteroclitus ranked first in both average biomass (126 g per $10 \mathrm{~m}$ ) and average numbers (177 per $10 \mathrm{~m})$. Pinfish Lagodon rhomboides ranked second in biomass at $68 \mathrm{~g}$ per $10 \mathrm{~m}$ and spot Leiostomus xanthurus second in number at 154 per $10 \mathrm{~m}$. Fish weight averaged $0.88 \mathrm{~g}$ and ranged from $0.03 \mathrm{~g}$ (juvenile pinfish and spot) to $400 \mathrm{~g}$ (southern flounder Paralichthys lethostigma).

Fish biomass, total numbers and numbers of species were lowest in January and February (Fig. 4). Numbers of fish reached a peak in April due primarily to the arrival of juvenile spot, which constituted $88 \%$ of the catch. The overall number of fish dropped in May as spot decreased from 1151 to 119 per $10 \mathrm{~m}$. In July and August numbers peaked again, when mummichog, sheepshead minnow Cyprinodon variegatus and striped killifish Fundulus majalis (all resident killifishes) made up about $80 \%$ of all fishes. Biomass first peaked in April ( $65 \%$ attributed to spot), leveled off for the next $3 \mathrm{mo}$, and reached the year's maximum in September, when pinfish composed $24 \%$ of the biomass. Species richness reached a maximum of 30 in August. The mean biomass of fishes collected in both habitats calculated on an area basis was $1.9 \mathrm{~g}$ per $\mathrm{m}^{2}$.

\section{Crustaceans}

Blue crab Callinectes sapidus and penaeid shrimp Penaeus aztecus, $P$. duorarum and $P$. setiferus were the 
Table 1. Fishes collected with block nets from Spartina alterniflora vegetation May 1986 through April 1987, listed in order of decreasing biomass. Rank by number of individuals in parentheses. Biomasses and numbers of individual fish are monthly averages per $10 \mathrm{~m}$ of marsh front. For total biomass or total number collected during year multiply by 96 . R: Resident; $\mathrm{T}$ : transient; $\mathrm{V} \cdot$ marine visitor. Blue $\mathrm{crab}$ and penaeid shrimp data given at end of table

\begin{tabular}{|c|c|c|c|c|c|}
\hline $\begin{array}{l}\text { Scientific and } \\
\text { common name }\end{array}$ & $\begin{array}{c}\text { Biomass } \\
\left(\mathrm{g} \times 10 \mathrm{~m}^{-1}\right)\end{array}$ & $\begin{array}{l}\text { Individuals } \\
\left(\times 10 \mathrm{~m}^{-1}\right)\end{array}$ & $\begin{array}{l}\text { Scientific and } \\
\text { common name }\end{array}$ & $\begin{array}{c}\text { Biomass } \\
\left(\mathrm{g} \times 10 \mathrm{~m}^{-1}\right)\end{array}$ & $\begin{array}{l}\text { Individuals } \\
\left(\times 10 \mathrm{~m}^{-1}\right)\end{array}$ \\
\hline $\begin{array}{l}\text { Fundulus heteroclitus } \\
\text { mummichog (R) }\end{array}$ & 126.0 & $176.7(1)$ & $\begin{array}{l}\text { Gobionellus boleosoma } \\
\text { darter goby }(\mathrm{T})\end{array}$ & 1.8 & $6.5(11)$ \\
\hline $\begin{array}{l}\text { Lagodon rhomboides } \\
\text { pinfish (T) }\end{array}$ & 67.7 & $10.3(8)$ & $\begin{array}{l}\text { Gobiosoma bosci } \\
\text { naked goby }(R)\end{array}$ & 1.1 & $1.9(12)$ \\
\hline $\begin{array}{l}\text { Leiostomus xanthurus } \\
\text { spot }(\mathrm{T})\end{array}$ & 63.1 & $154.5(2)$ & $\begin{array}{l}\text { Archosargus probatocephalus } \\
\text { sheepshead }(\mathrm{T})\end{array}$ & 1.1 & $<0.1 \quad(28)$ \\
\hline $\begin{array}{l}\text { Cyprinodon variegatus } \\
\text { sheepshead minnow (R) }\end{array}$ & 35.7 & $49.1 \quad(4)$ & $\begin{array}{l}\text { Eucinostomus gula } \\
\text { silver jenny }(T)\end{array}$ & 1.0 & $0.2(18)$ \\
\hline $\begin{array}{l}\text { Fundulus majalis } \\
\text { striped killifish }(\mathrm{R})\end{array}$ & 32.6 & $51.6(3)$ & $\begin{array}{l}\text { Chasmodes bosquianus } \\
\text { striped blenny }(\mathrm{T})\end{array}$ & 0.9 & $0.1(24)$ \\
\hline $\begin{array}{l}\text { Eucinostomus argenteus } \\
\text { spotfin mojarra (T) }\end{array}$ & 18.9 & 13.2 & $\begin{array}{l}\text { Lutjanus griseus } \\
\text { gray snapper }(\mathrm{T})\end{array}$ & 0.7 & $0.4(16)$ \\
\hline $\begin{array}{l}\text { Paralichthys lethostigma } \\
\text { southern flounder (T) }\end{array}$ & 17.4 & $0.1 \quad(20)$ & $\begin{array}{l}\text { Paralicthys albigutta } \\
\text { gulf flounder }(\mathrm{T})\end{array}$ & 0.4 & $<0.1 \quad(30)$ \\
\hline $\begin{array}{l}\text { Mugil curema } \\
\text { white mullet }(\mathrm{T})\end{array}$ & 13.8 & $11.9(6)$ & $\begin{array}{l}\text { Sciaenops ocellata } \\
\text { red drum (T) }\end{array}$ & 0.4 & $<0.1(32)$ \\
\hline $\begin{array}{l}\text { Menidia menidia } \\
\text { Atlantic silverside }(\mathrm{R})\end{array}$ & 11.7 & $11.7(7)$ & $\begin{array}{l}\text { Symphurus plagiusa } \\
\text { black cheek tonguefish (T) }\end{array}$ & 0.3 & $0.1(22)$ \\
\hline $\begin{array}{l}\text { Orthopristis chrysoptera } \\
\text { pigfish }(\mathrm{T})\end{array}$ & 9.1 & 1.5 (13) & $\begin{array}{l}\text { Lutjanus synagris } \\
\text { lane snapper (V) }\end{array}$ & 0.2 & $<0.1(26)$ \\
\hline $\begin{array}{l}\text { Paralichthys dentatus } \\
\text { summer flounder }(\mathrm{T})\end{array}$ & 8.0 & $1.0(14)$ & $\begin{array}{l}\text { Evorthodus lyricus } \\
\text { lyre goby (T) }\end{array}$ & 0.1 & $<0.1 \quad(25)$ \\
\hline $\begin{array}{l}\text { Opsanus tau } \\
\text { oyster toadfish }(\mathrm{R})\end{array}$ & 7.8 & $0.2(17)$ & $\begin{array}{l}\text { Syngnathus louisianae } \\
\text { chain pipefish }(\mathrm{T})\end{array}$ & $<0.1$ & $<0.1 \quad(27)$ \\
\hline $\begin{array}{l}\text { Bairdiella chrysoura } \\
\text { silver perch }(\mathrm{T})\end{array}$ & 7.7 & $0.5(15)$ & $\begin{array}{l}\text { Caranx hippos } \\
\text { crevalle jack (V) }\end{array}$ & $<0.1$ & $<0.1 \quad(29)$ \\
\hline $\begin{array}{l}\text { Cynoscion nebulosus } \\
\text { spotted seatrout }(\mathrm{T})\end{array}$ & 6.0 & 0.2 (19) & $\begin{array}{l}\text { Selene vomer } \\
\text { lookdown (V) }\end{array}$ & $<0.1$ & $<0.1 \quad 33\}$ \\
\hline $\begin{array}{l}\text { Mugil cephalus } \\
\text { striped mullet (R) }\end{array}$ & 5.8 & $9.5(9)$ & $\begin{array}{l}\text { Syngathus fuscus } \\
\text { northern pipefish (T) }\end{array}$ & $<0.1$ & $<0.1 \quad(35)$ \\
\hline $\begin{array}{l}\text { Anchoa mitchilli } \\
\text { bay anchovy }(\mathrm{R})\end{array}$ & 4.5 & $8.6(10)$ & $\begin{array}{l}\text { Stephanolepis hispidus } \\
\text { planehead filefish }(\mathrm{T})\end{array}$ & $<0.1$ & $<0.1 \quad(34)$ \\
\hline $\begin{array}{l}\text { Synodus foetens } \\
\text { inshore lizardfish }(\mathrm{T})\end{array}$ & 3.7 & $0.1 \quad(23)$ & $\begin{array}{l}\text { Prionotus evolans } \\
\text { striped searobin (V) }\end{array}$ & $<0.1$ & $<0.1$ (31) \\
\hline \multirow[t]{2}{*}{$\begin{array}{l}\text { Sphyraena barracuda } \\
\text { great barracuda (V) }\end{array}$} & 1.9 & 0.1 (21) & $\begin{array}{l}\text { Callinectes sapidus } \\
\text { blue crap }\end{array}$ & 187.6 & 5.5 \\
\hline & & & Penaeus ( 3 species) & 24.1 & 9.3 \\
\hline
\end{tabular}

principal invertebrate nekton group (Table 1). Grass shrimp Paleomonetes spp. were sometimes caught in great numbers, but were not enumerated because of their ability to resist capture by hiding at the base of the wet vegetation or in residual pools on the marsh, behavior not observed in blue crab and penaeid shrimp. Xanthid crabs were rarely taken.

Seasonal trends in relative biomass of blue crab and penaeid shrimp were similar. No shrimp and less than $0.2 \%$ of blue crab were collected from January to March. Monthly average biomass was greatest in summer (July to September): $401 \mathrm{~g}$ per $10 \mathrm{~m}$ for blue crab and $76 \mathrm{~g}$ per $10 \mathrm{~m}$ for shrimp. Numbers of blue crab decreased from an average of 10.3 per $10 \mathrm{~m}$ in spring to 2.8 in fall, whereas the greatest number of shrimp per $10 \mathrm{~m}$ of marsh front, 23.4, was collected in summer.

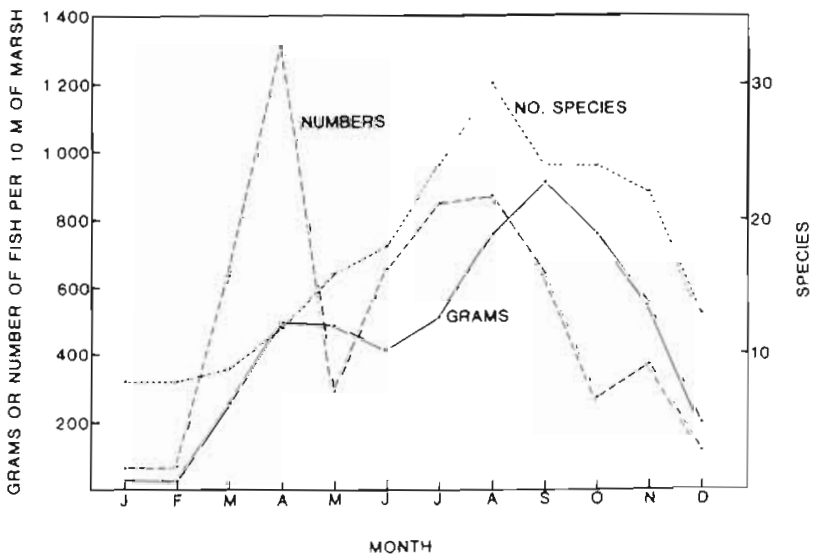

Flg. 4. Average fish biomass in $g$ (solid line), average numbers of fish (dashed line) collected from each $10 \mathrm{~m}$ of marsh front, and total number of fish species collected (dotted line) by month 
Blue crab averaged $34.2 \mathrm{~g}(n=527)$ and penaeid shrimp averaged $2.6 \mathrm{~g}(n=890)$.

\section{Channel vs rivulet}

Channel and rivulet stations had different species communities. Relative distributions by number and weight of 18 species of fish plus blue crab and penaeid shrimp in these 2 habitats are shown in Fig. 5. Of killifishes, white mullet Mugil curema and spotfin mojarra Eucinostomus argenteus, $50 \%$ or more by weight were captured from rivulet vegetation. Most biomass of all other species was taken from the channel marsh.

Average fish biomass was $501 \mathrm{~g}$ per $10 \mathrm{~m}$ in rivulet habitats and $398 \mathrm{~g}$ per $10 \mathrm{~m}$ in channel habitats, but month/habitat differences are not significant when repeated-measure analysis of variance is applied. However, a seasonal pattern is apparent (Fig. 6). From February through September rivulet biomass was higher than channel biomass. In fall and early winter this pattern reversed, due mainly to the abundance of relatively large pinfish and paralichthid flounder. Although the majority of the species occupied the channel marsh (Fig. 5), more individual fish were found in rivulet marsh (785 vs 236 per 10 m) $(p=0.0547$; repeated-measures ANOVA). Seasonal trends were similar in the 2 habitats and average numbers of fish did not differ appreciably from
December through April (Fig. 7). However, during summer, the number of individuals from the rivulet habitat was an order of magnitude greater than the number collected from the channel marsh due to the abundance of killifishes.

\section{DISCUSSION}

Regularly-flooded marsh surface was used by resident fishes and by estuarine-dependent transient juvenile fishes and macrocrustaceans. Boesch \& Turner (1984) were only partially correct when they stated $\therefore$.. salt marshes are intertidal and for the most part the animals of concern do not live amidst the grass blades...' Obviously natant organisms cannot live in this habitat when the surface is drained at low tide, but for several hours around high tide the marsh is inundated, providing expanded habitat with a substantial feeding opportunity and reduction in predation risk. Species identified in this study may spend approximately one-third of their time living in the Spartina vegetation. Water depth over the marsh surface was $>10 \mathrm{~cm}$ for $>4 \mathrm{~h}$ out of the ca $12 \mathrm{~h}$ tidal cycle during average neap tides and was even deeper during spring tides.

The dominant fish by weight and number in the flooded Spartina marsh was mummichog. Kneib \& Stiven (1978) recognized the role of this species in the transfer of energy from salt marshes to the open estu-
Fig. 5. Relative distribution between 2 marsh habitats of the 20 most abundant species. For example, $58 \%$ by number and $62 \%$ by weight of spot came from channel marsh
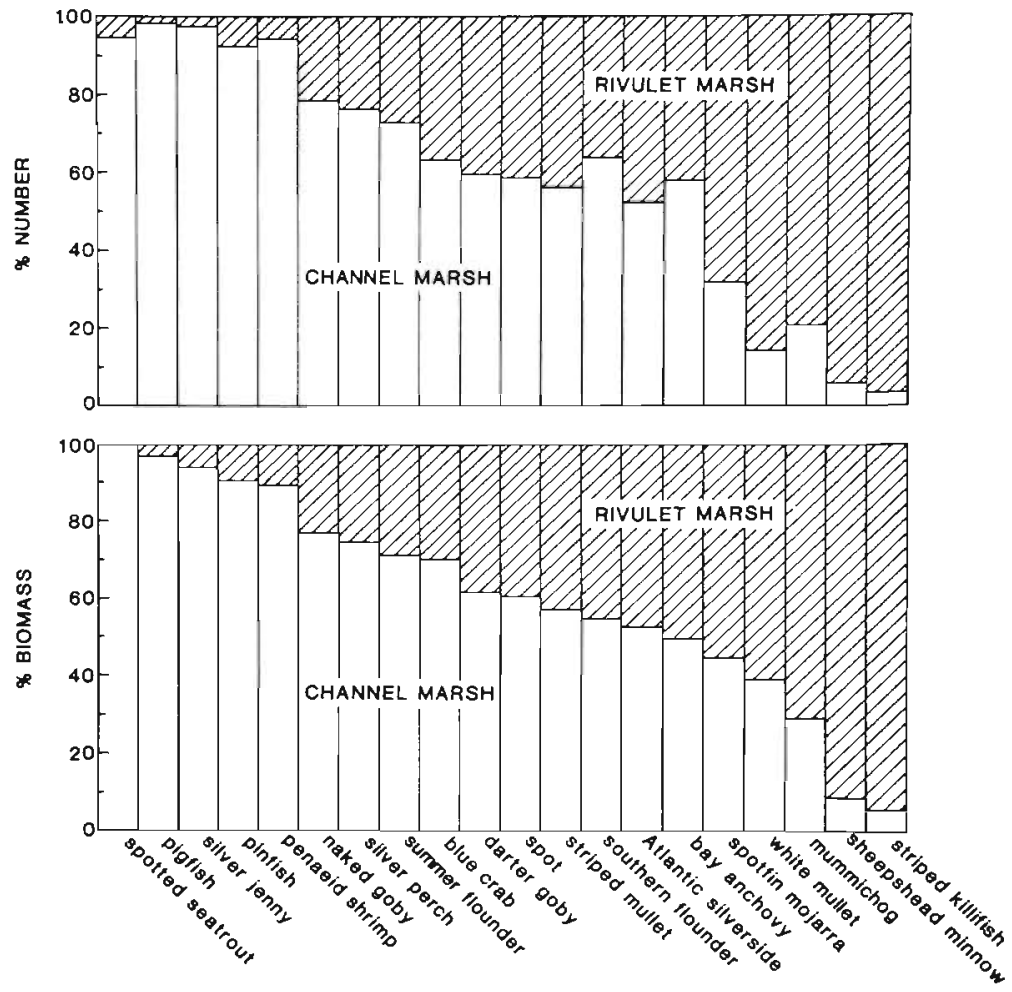


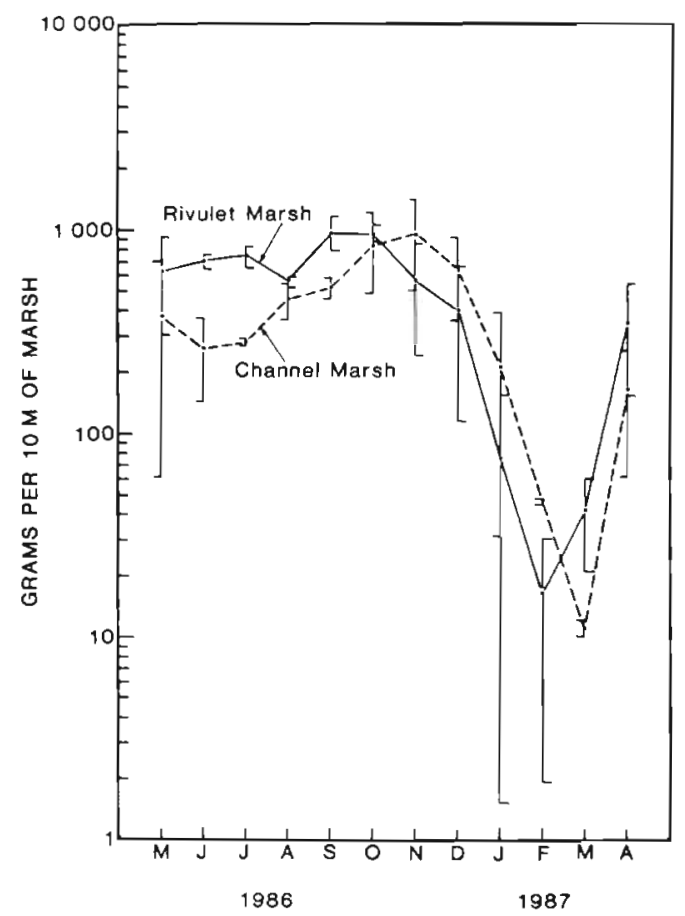

Fig. 6. Biomass of fish per $10 \mathrm{~m}$ of channel marsh (dashed line) and rivulet marsh (solid line) by month. Error bars: \pm 1 standard error (error bar ends towards left are for channel marsh $_{i}$ towards right are for rivulet marsh)

ary. They reported that mummichog fed on small crustaceans, insects, algae, detritus, and fecal pellets in the marsh and then returned to tidal creeks and bays at low tide where they provided forage for important commercial species. This species and the 2 other killifishes provided an average monthly wet weight of $20 \mathrm{~g}$ for each meter of marsh edge sampled, which was about $43 \%$ of the total fish biomass.

Spot was the second most abundant species. Putative spot nursery areas are shallow waters over muddy substrates (Bozeman \& Dean 1980), tidal streams and rivulets as well as non-tidal bays (Currin et al. 1984), and to a lesser extent adjacent seagrass meadows (Weinstein \& Brooks 1983). This study suggests that marshes, or at least marsh fringes, can be added to the list of nursery habitats for spot. Flooded marsh may provide a settling site for spot juveniles making the transition from pelagic to benthic life. Unlike spot, Atlantic croaker Micropogonias undulatus were never taken in the marsh, even though spot and croaker larvae occur together in late winter in the nearby main channels in high densities (Hettler \& Chester unpubl.). Atlantic croaker juveniles can be collected with trawls in the Newport River. Their total absence from the marsh surface indicates that this species prefers deeper water when it is available (Weinstein \& Brooks 1983).

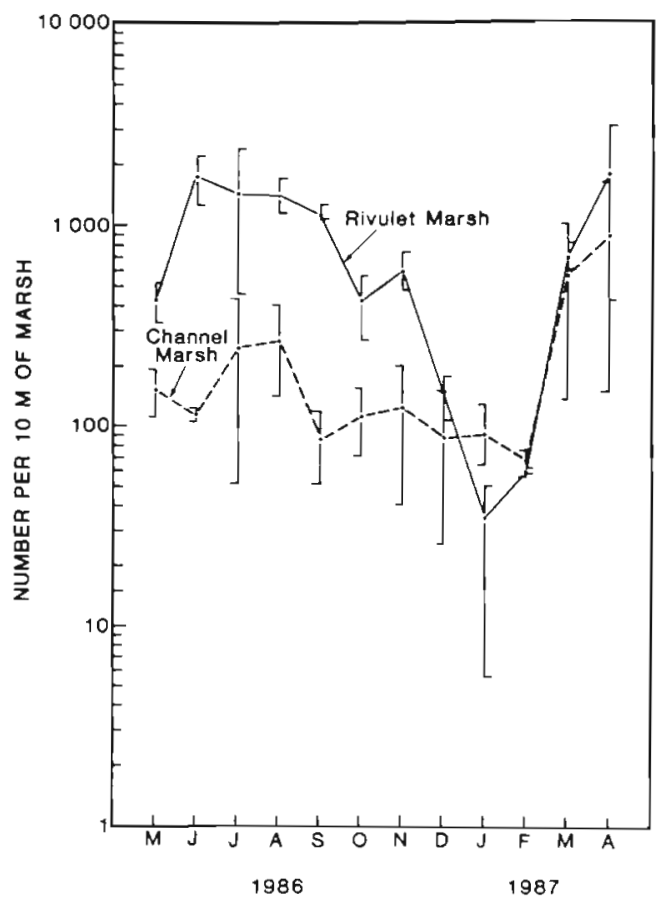

Fig. 7. Number of fish per $10 \mathrm{~m}$ of channel marsh (dashed line) and rivulet marsh (solid line) by month. Errors bars as in Fig. 6

Similarly, Atlantic menhaden Brevoortia tyrannus, a dominant estuarine fish, was never taken in the marsh. Menhaden larvae are among the most abundant species collected from February to April in the Newport River estuary (Thayer et al. 1974). Their absence from the marsh as juveniles is probably related to their filterfeeding behavior. As juveniles and adults they swim in tight schools through the water column and filter out food particles. The marsh structure would preclude this feeding method.

Regularly-flooded Spartina alterniflora marsh was used by $>50 \%$ of the fishes reported from adjacent estuarine waters. I collected 35 of the 67 teleost species found in the lower Newport River estuary by Turner \& Johnson (1973) who used haul seines, trawls and gill nets in various habitats. They found a mean fish biomass (juvenile and adult) from the littoral zone of the estuary for the year to be $0.93 \mathrm{~g}$ per $\mathrm{m}^{2}$, compared to $1.9 \mathrm{~g}$ per $\mathrm{m}^{2}$ in my study, which I extrapolated (considering the limitations of measuring the trap efficacy area mentioned in the methods) from an estimate of the area potentially containing fish behind the block nets. Their estimates included Atlantic menhaden. Atlantic croaker and rough silverside Membras martinica, none of which I collected. Killifishes were not important in the littoral zone in their study, but were very significant in my study.

In the study area, species composition and abundance varied depending on the physiography of the mi- 
crohabitat. Microhabitats (rivulet and channel marshes) were different in fish community structure, even though vegetation and sediment characteristics in the marshes were similar. Rivulet marsh contained more nekton biomass and numbers per meter of edge than channel marsh, except from October to January. The zone in front of the rivulet marsh is a shallow-slope, low-energy, intertidal microhabitat in contrast to the zone in front of the channel marsh, which is a deep, higher energy, subtidal habitat. Invertebrate infauna in these 2 zones are probably different as is predation pressure. In front of the channel marsh, piscivorous fishes could forage throughout the tidal cycle on fishes driven off the marsh surface at low tide seeking refuge in the shallow water adjacent to the channel, but not in the residual pools adjacent to the rivulet marsh at low tide. These pools and Stream Order 1 drainages provide refuge for species like killifishes during this period. Rozas et al. (1988) demonstrated that rivulets were preferred points of access for small fishes into freshwater tidal marshes, which provides fishes adapted for survival in the shallow intertidal area a safer haven than the more risky subtidal habitat. They show that large predators are rare in the intertidal zones and that these zones provide an expanded foraging area. Rozas \& Odum (1987) found that use of the marsh by fish increased with decreasing stream order which is directly related to a decrease in predators, whereas blue crab tended to decrease in numbers with decreasing stream order. Kneib (1986) states that blue crab are the major predator on adult mummichog in the intertidal zone. Avoidance of this predator by killifish is apparently effected in the rivulet habitat, as within this habitat, I captured $50 \%$ fewer blue crab here than in the nearby channel marsh. McIvor \& Odum (1988) found differences in fish densities and species composition in adjacent marsh surface microhabitats on the same tidal freshwater creek and attributed the differences to the water depth in front of the marsh, i.e depositional vs erosional creek bottom. They suggest that at the depositional bank both lower predation and higher food availability may be qualities that allow a larger pool of fishes to invade the marsh as it floods.

Assessment of the marsh value as a fisheries nursery zone must include microhabitat differences within the particular system. Further, studies are needed to determine the distance of penetration into the marsh by the nekton. We must re-examine the question suggested by Turner (1977): Is the edge-effect the more important property of marsh habitat for direct use by nekton or is total marsh area equally important? Marshes vary from narrow fringes along high energy shorelines to broad expanses such as the Georgia (USA) marshes. A highly reticulated marsh may be more productive for fisheries organisms than a solid marsh of the same area. Without understanding nekton abundance and distribution in various marsh microhabitats, the value of the 'marsh' for fisheries production cannot be accurately assessed.

Acknowledgements. I thank those at the Beaufort Laboratory who helped with sampling (especially Victoria Thayer, John Burke and Don Jacobson) and with the preparation of this manuscript (David Peters, Alexander Chester and David Colby). One anonymous reviewer helped substantially with the final revision

\section{LITERATURE CITED}

American Society for Testing and Materials (1963). Standard methods for particle size analysis of soils. A.S.T.M. designation D422-63, American Society for Testing and Materials, Philadelphia

Boesch, D. F., Turner, R. E. (1984). Dependence of fishery species on salt marshes: the role of food and refuge Estuaries 7: 460-468

Bozeman, E. L., Jr, Dean, J. M. (1980). The abundance of estuarine larval and juvenile fish in a South Carolina intertidal creek. Estuaries 3: 89-97

Currin, B. M., Reed, J. P., Miller, J. M. (1984). Growth, production, food consumption, and mortality of juvenile spot and croaker: a comparison of tidal and nontidal nursery areas. Estuaries 7: 451-459

Gilmore, R. G., Cooke, D. W., Donohoe, C. J. (1982). A comparison of the fish populations and habitat in open and closed salt marsh impoundments in east-central Florida. Northeast Gulf Sci. 5: 25-37

Kneib, R. T. (1986). The role of Fundulus heteroclitus in salt marsh trophic dynamics. A.m. Zool. 26: 259-269

Kneib, R. T., Stiven, A. E. (1978). Growth, reproduction, and feeding of Fundulus heteroclitus (L.) on a North Carolina salt marsh. J. exp. mar. Biol. Ecol. 31: 121-140

Lipcius, R. N., Subrahmanyam, C. B. (1986). Temporal factors influencing killifish abundance and recruitment in Gulf of Mexico salt marshes. Estuar. coast. Shelf Sci. 22 101-114

Mclvor, C. C., Odum, W. E. (1986). The flume net: a quantitative method for sampling fishes and macrocrustaceans on tidal marsh surfaces. Estuaries 9: 219-224

McIvor, C. C., Odum, W. E. (1988). Food, predation risk and microhabitat selection in a marsh fish assemblage. Ecology 69: $1341-1351$

Odum, W. E. (1984). Dual-gradient concept of detritus transport and processing in estuaries. Bull. mar. Sci. 35: $510-521$

Rogers, S. G., Targett, T. E., Van Sant, S. B. (1984). Fishnursery use in Georgia salt-marsh estuaries: the influence of springtime freshwater conditions. Trans. Am. Fish. Soc 113: 595-606

Rozas, L. P., Hackney, C. T. (1984). Use of oligohaline marshes by fishes and macrofaunal crustaceans in North Carolina. Estuaries 7: 213-224

Rozas, L. P., Mclvor, C. C., Odum, W. E. (1988). Intertidal rivulets and creekbanks: corridors between tidal creeks and marshes. Mar. Ecol. Prog. Ser. 47: 303-307

Rozas, L. P., Odum, W. E. (1987). Use of tidal freshwater marshes by fishes and macrofaunal crustaceans along a marsh stream-order gradient. Estuaries 10: 36-43

Talbot, C. W., Able, K. W. (1984). Composition and distribution of larval fishes in New Jersey high marshes. Estuaries 7: $434-443$ 
Thayer, G. W., Hoss, D. E., Kjelson, M. A., Hettler, W F. Jr. LaCroix, M. W. (1974). Biomass of zooplankton in the Newport River estuary and the influence of postlarval fishes. Chesapeake Sci. 15: 9-16

Tumer, R. E. (1977). Intertidal vegetation and commercial yields of penaeid shrimp. Trans. Am. Fish. Soc. 106: 411-416

Turner, W. R., Johnson, G. N. (1973). Distribution and relative abundance of fishes in Newport River, North Carolina. NOAA Tech. Rep. NMFS SSRF-666

This article was presented by Dr C. D. Levings, West Vancouver, B.C., Canada
Weinstein, M. P. (1979). Shallow marsh habitats as primary nurseries for fishes and shellfish, Cape Fear River, North Carolina. Fish. Bull. U.S. 77: 339-357

Weinstein, M. P., Brooks, H. A. (1983). Comparative ecology of nekton residing in a tidal creek and adjacent seagrass meadow: community composition and structure. Mar. Ecol. Prog. Ser. 12: 15-27

Zimmerman, R. J., Minello, R. J. (1984). Densities of Penaeus aztecus, Penaeus setiferus, and other natant macrofauna in a Texas salt marsh. Estuaries 7: 421-433

Manuscript first received: October 3,1988

Revised version accepted: May 10, 1989 